\title{
Sex Offender Community Notification Law Reform: A Call for More Active, Consistent, and Detailed Information about High-Risk Offenders
}

\author{
Michelle L. Beshears ${ }^{1}$, Mike L. Beshears ${ }^{2}$, Dena Weiss ${ }^{3} \&$ Catherine D. Crocker ${ }^{4}$ \\ ${ }^{1}$ School of Security and Global Studies, Assistant Professor of Criminal Justice, PhD., American Public University \\ System, Charles Town, West Virginia, USA \\ ${ }^{2}$ School of Security and Global Studies, Assistant Professor of Criminal Justice, PhD., American Public University \\ System, Charles Town, West Virginia, USA \\ ${ }^{3}$ School of Security and Global Studies, Assistant Professor of Criminal Justice, PhD., American Public University \\ System, Charles Town, West Virginia, USA \\ ${ }^{4}$ Research/Editor, PhD., Hermitage, Tennessee, USA \\ Correspondence: Michelle L. Beshears, Ph.D., School of Security and Global Studies, Assistant Professor of Criminal \\ Justice, American Public University System, Charles Town, West Virginia, USA.
}

Received: March 13, 2017

doi:10.11114/ijsss.v5i5.2361
Accepted: April 13,2017 Available online: April 18, 2017

URL: https://doi.org/10.11114/ijsss.v5i5.2361

\begin{abstract}
There has been quite a bit of controversy surrounding the enforcement of sex offender registration and community notification laws. A major argument against such laws involves the lumping of all sex offenders into a single category, which hinders offender management and public safety. Further exacerbating this problem is the fact that less than $35 \%$ of state registries provide the information necessary for citizens to make informed decisions regarding their safety, such as the victim's age or gender. In some cases, law enforcement will go door-to-door and in other cases, community members need to look up information on their own. Misinformation and inconsistencies can cause unnecessary angst among community members. Therefore, states should consider the value of enacting uniformed legislation that is more active in its pursuit to provide consistent and detailed information about high-risk offenders and the offense(s) committed. This will better enable community members to more effectively form their own risk assessments and make better informed decisions.
\end{abstract}

Keywords: sex offender, community notification, risk assessment

\section{Introduction}

Annually, approximately 300000 rapes are committed by sex offenders, over 3.7 million women are confronted yearly with unwanted sexual activity (Bonnar-Kidd, 2010), and 3.2\% of U.S. youth experience child sexual abuse (Finkelhorn, 2009), resulting in public outcry and concern regarding continued growth of sex related abuses and crimes. In an effort to reduce assault occurrences, laws requiring some form of sex offender registration have been passed. In brief, there have been three prominent laws - The Jacob Wetterling Act of 1994, Megan's Law in 1996, and the Adam Walsh Child Protection and Safety Act of 2006. The original intent of the registry was to protect citizens by listing the registered sex offenders' (RSOs) names and addresses along with a photograph. However, the passing of the registry laws has led to the assessment of recidivism rates and a debate of where sex offenders should live and why, resulting in neglect of the issues of the registry in terms of what information should or should not be included as well as the how of community notification and the perspectives of law-abiding citizens.

While sex offender management is a high profiled topic with respect to public safety (Freeman-Longo, 2001), the controversy regarding sex offender registration and community notification has primarily focused upon legislative issues with respect to constitutional rights - the rights of the citizenry to protect themselves and their children as well as the rights of the RSOs in terms of his and or her basic freedoms and privacy (Anderson, Sample, \& Cain, 2015; Miller, 2010; Skelley, 2011). This has resulted with states endorsing sex offender community notification laws in an effort to protect communities from sexual predators, but little or no consideration has been placed as to the method of the 
notification and what information is pertinent and warranted in terms of the notification and the registry. Furthermore, how the notification and registry information is perceived by the public has gone unnoticed.

\section{Literary Overview}

\subsection{Brief Historical Overview of Registry Laws}

After the abductions and subsequent murders of Adam Walsh in 1991 and Megan Kanka and Jacob Wetterling both in 1994, laws were enacted in memory of these children for the express purpose of protecting other families and children from undergoing such horrific occurrences (Stevens, 2012). The concept behind these laws was that requiring sex offenders to register and increasing the attention of the community-at-large of RSOs' locations would possibly act as a further deterrent regarding recidivism as well as better protect the community (Durling, 2006; Duwe \& Donnay, 2010; Zandbergen \& Hart, 2006). Further, the belief and intent was that these laws would in turn hold sex offenders responsible and accountable for their crimes by imposing tougher penalties and restricting access to children (Stevens, 2012). The three laws are as follows:

\subsubsection{Jacob Wetterling Act of 1994}

First of all, it should be noted that prior to the passage of this act, there were no mandates requiring states or agencies to track the movement of sex offenders once they had been released from prison ("Jacob Wetterling," 2010). The result of the Wetterlings and others lobbying for such a law was the establishment of state guidelines. Specifically, the Jacob Wetterling Crimes Against Children and Sex Offender Registration Act of 1994 required the annual or quarterly tracking of sex offenders as to their residence upon their release from prison. Annual tracking was limited to 10 years for nonviolent sex crime offenders and yearly quarterly tracking for the remainder of the violent sex offender's life.

\subsubsection{Megan's Law of 1996}

Megan's Law is a 1996 amendment to the 1994 Jacob Wetterling Act (Stevens, 2010). This amendment legalized the public dissemination of information from the sex offender registry (SOR) maintained by the states and this information could also be disclosed for legal purposes as determined by state law ("Office of Justice Programs," n.d.). Furthermore, as a result of Megan's Law, the public notification of RSOs' residency was no longer considered a recommendation or guideline (Jacob Wetterling Crimes Against Children and Sex Offender Registration Act, 1994; Stevens, 2010), but became a requirement for all state and local law enforcement agencies ("Office of Justice Programs,"n.d.).

\subsubsection{Adam Walsh Child Protection and Safety Act of 2006}

The Adam Walsh Child Protection and Safety Act included the following additional stipulations and mandates: a baseline standard for the SOR and notification; inclusion of 212 Indian Tribes within the legal definition of the term, jurisdiction; the SOR is to include all state, territory, tribal, federal, military, and some foreign sex offenders; creation of SMART sentencing, monitoring, apprehending, registering, and tracking; and the establishment of the sex offender management assistance (SOMA) program under the United States Justice Department ("Office of Justice Programs,"n.d.).

With the passage of each ensuing sexual offender law, the parameters were broadened in an effort to better ensure the protection of the law-abiding citizenry, especially that of the children. However, attention and opinion began to be divided in terms of whether the rights of the offenders were being violated, especially in terms of living space location (Grubesic, Mack, \& Murray, 2007; Saxer, 2009; White, 2008), if there should be more distinct or broader guidelines as to the registry and notification processes (Ferrandino, 2012; Levenson \& D'Amora, 2007), and various other concerns, such as the effects of the laws on recidivism (Bonnar-Kidd, 2010; Chajewski \& Mercado, 2009) and the effect of media on public opinion regarding sex offenders and related issues (Durling, 2006; Fortney, Levenson, Brannon, \& Baker, 2007; Levenson \& D'Amore, 2007). However, the impact these guidelines had on the public as well as how it would be interpreted by the average member of society was virtually ignored.

\subsection{Sex Offender Registries}

SORs are required in all 50 of United States, Washington D.C., Puerto Rico, and Guam (Office of Justice Programs, n.d.). These state and territory developed registries are required to include the following electronically stored data on each RSO:

- Names and aliases,

- Internet identifiers and addresses,

- Telephone numbers,

- Social security number,

- Residence and or lodging, 
- Travel information,

- Immigration documents,

- Employment information,

- Professional licenses,

- School information (student or planning to be a student),

- Vehicle information,

- Date of birth,

- Physical description,

- Text of registration offense,

- Criminal history and other criminal justice information,

- Current photograph,

- Fingerprints and palm prints,

- DNA, and

- Driver's license or identification card. (“U.S.Department of Justice,”2008)

In addition to this data, individual states and territories have the legal right to require additional information ("U.S.Department of Justice," 2008). Nevertheless, there continues to be a lack of uniformity from state to state and territory to territory, giving rise to problems associated with the registry (Tewksbury \& Lees, 2006).

\subsubsection{Issues with Sex Offender Registries}

There are some experts who believe that the federally mandated system places too many offenders within the registry (Cauffman et al., 2007; Ferrandino, 2012). There are also those who argue that it is crucial to understand the characteristics of the individuals on the registries. Others feel that sex offenders should be classified into a relatively homogeneous group (Levenson \& D'Amora, 2007). However, the argument against categorizing sex offenders as a homogeneous group is the issue that one may lose sight of the individual person (Wagner, 2011), which would likely affect the conclusions drawn from the public who are viewing the data (Payne, Tewksbury, \& Mustaine, 2010). Thus, conflicting opinions exist and the root needs to be analyzed more deeply in order to achieve consistency among the registry lists in terms of who and what characteristics and data should be displayed, which would increase the utility and accuracy of the registries (Cauffman et al., 2007; Ferrandino, 2012).

At present, researchers or interested parties needing to access SOR information must search each state or territory individually because a national SOR database does not exist (Ackerman, Harris, Levenson, \& Zgoba, 2011; Newburn, 2010). Furthermore, in spite of the required data, there is no uniformity or consistency across the SOR databases as each state determines the order and organization of their registry. A sample of all state sex offender online registries (except Maryland, which was not accessible) was taken by Ferrandino (2012) wherein a content analysis was performed on each state's online SOR with one offender being chosen from each list. The number of variables for each state were marked and used to represent the amount of social construction and social reality variables present in each state. The results showed there were many identifiers of an offender's appearance and geographical area, but there was a broad disparity of information in terms of indicating the social reality of the offenses, such as age and gender of the offender in relation to the victim, relationship of the victim and offender, method of committing the offense, and sentence received for the crime (Ferrandino, 2012). Less than 35\% of the state registries reviewed provided information on the victim's age or gender. Furthermore, only $4.5 \%$ of the states provided information on targets, victim-offender relationships, modus operandi of the offender, or a list of nearby daycare facilities and schools. The lack of social reality variables was seen in the percentage of states (> 90\%) that did not include public information, such as offender sentence, rental property owned by offender, list of schools, treatment status, victim-offender relationship, and an offender target section (Ferrandino, 2012).

SORs exist predominantly because the technological means are available and can deliver the information on demand at no cost to the user via the internet (DeMichele \& Payne, 2009). The registries are an additional tool that parents may utilize to ensure the safety of their children ("U.S.Department of Justice," 2008). For instance, the state of Rhode Island Registry affirmed the SOR is not for increasing fear in the community, but rather it is the idea of law enforcement that an informed public is a safe one (Tewksbury, 2005). However, there are two issues regarding SORs that have not been addressed by researchers and could hinder the effectiveness of SORs being a tool for community safety (Galeste, Fradella, \& Vogel, 2012). The first issue is concerning the consistency of the SOR information among states and 
territories, and the second issue is an extension of the first in that determination has not been made whether social construction of sex offenders is a competing or complimentary view to the social reality of sex offenses (Galeste et al., 2012). Based on a Florida sample, Brannon, Levenson, Fortney, and Baker (2007) found most people had an incorrect impression regarding sex offender recidivism rates as well as misperceptions about mental illness and victim or offender relationships. This sample population were also very punitive in their thinking. The indi viduals in the sample stated they would prefer a sex offender to spend on average of "39 years in prison and 42 years of probation" ("Registered Sex Offender,"2013, p. 5).

\section{Method}

\subsection{Participants}

The participants were a purposeful sample of 20 individuals ranging in age from 20 to approximately 65 , who were current homeowners or renter residents of Mountain Home, Arkansas, and received the invitation to participate during the sheriff deputies' routine community notification of those living next to or near a sex offender. The invitation letter indicated the purpose of the study and a request for their participation in a private interview regarding their experiences of living in close vicinity of a RSO. Phone and contact information were provided for the purpose of asking questions regarding the study if desired and to volunteer to participate. Volunteers who chose to participate were prescreened and it was verified with the sheriff's office that they themselves were not RSOs or a known relative of the RSO. Of the approximately 1500 invitations to participate handed out by the sheriff's deputies, there were only 20 volunteers. No demographic data were collected due to the focus being on the lived experience of the citizens, not their gender, age, or other factors.

\subsection{Data Collection}

Face-to-face, individual, audio-recorded interviews were scheduled and held, whereby the informed consent form was presented and reviewed with the participants prior to the interview beginning. Due to the potential sensitivity of the topic, the participants were verbally reminded at the beginning of the interview that they could refuse to answer any question or stop the interview at any time; however, all interviews were completed in their entirety. Debriefing was conducted following each interview and arrangements made for member checking of the transcripts.

\subsection{Data Analysis}

The analysis and coding process involved implementation of Moustakas' (1994) modified Stevick-Colaizzi-Keen descriptive design for qualitative research (Chwalisz, Shah, \& Hand, 2008). The first step was analysis of each individual statement with respect to whether it was descriptive of the experience of living next to or near a registered sexual offender. Nonrelated or nondescriptive responses were not included in the initial review of the responses. The second step involved listing the relevant statements with elimination of repetition. The statements are what Moustakas (1994) references as "invariant horizons or meaning units of the experience" (p. 122). The third step was to identify and group the invariant meaning units into themes. These themes or categories were then synthesized into a textured description of the experience as related by the participants. Lastly, a textured structural description of the meanings derived from the experiences was completed (Moustakas, 1994).

Through the outlined process, the researcher discovered specific themes emerging from the participants' experiences. The findings were then used to understand what living next to or near a sex offender entails. Through the process of phenomenological study, information builds upon the prior question to develop themes and findings (Groenewald, 2004). The process was extensive as each interview was transcribed, read, interpreted, coded, and analyzed per the modified Stevick-Colaizzi-Keen, so the findings could be applied in support of the true lived experience of the participants while providing potential connections to the concepts (Moustakas, 1994).

Additionally, patterns, repetitions, and themes were noted and the responses coded by constant comparative analysis (Glaser \& Strauss, 2009). The process of constant comparative analysis, noting of similarities and differences, was applied to the interview responses as well as the field notes regarding body language and facial expressions (Glaser \& Strauss, 2009). The intent of this process was the development of a cohesive description of the perceptions of individuals' responses to having a sex offender living in their neighborhood. These perceptions are related in the participants' own words. 


\subsubsection{Themes}

Table 1. Summary of Themes and Participant Responses

\begin{tabular}{llll}
\hline Themes & $\begin{array}{l}\text { Participants who } \\
\text { expressed } \\
\text { concern }\end{array}$ & $\begin{array}{l}\text { Participants } \\
\text { expressed } \\
\text { neutral/no concern }\end{array}$ & $\begin{array}{l}\text { Percentage of } \\
\text { Participants } \\
\text { Responding }\end{array}$ \\
\hline 1. Safety of Children & $\begin{array}{l}2,3,4,5,7,9,10,11, \\
\text { 13, 15, 16,17, 18, 20 }\end{array}$ & $1,6,12,14,19$ & $95 \%$ \\
2. Personal Knowledge about the & $2,3,5, * 8,9,10,13$, & $1,6, * 8,12,20$ & $70 \%$ \\
$\quad$ Offender and/or Offense & $14,15,16$ & 1,12, & $50 \%$ \\
3. Extra Precautions & $3,4,9,10,11,15,16$, & 1 & $30 \%$ \\
4. Perceptions about Notification & $17,18,20$ & & \\
Process** & $2,4,5,8,11$ & $1,6,12,19$ & $90 \%$ \\
5. Effect on Lifestyle & $2,3,4,5,7,9,10,11$, & \\
\hline
\end{tabular}

Note: *Theme 2: \#8 had mixed feelings - no current concern as the RSO was not deemed a threat, but would be concerned for a different offence. **The category of concerned represents those who expressed positive responses to the notification process; neutral/no concern category represents those who expressed negative or neutral responses about the notification process.

\section{Results}

The following comments were garnered from 20 interviews with people in a rural Arkansas area who lived near or next door to a level 3 or 4 RSO whose offense involved children. Interestingly, while the interview questions were focused on the participants' personal experiences regarding their lifestyle and possible effects close proximity with a sex offender had on their lives, the notification process arose as an independent central theme. Further, during the course of the conversational interviews, it became clear that those who had additional knowledge about the offender had modified their lifestyle accordingly. For example, Participant \#17 shared, "I used to be able to let the kids out to play and not worry about them" and both Participants \#9 and \#18 felt the need to be more mindful of their grandchildren when they visited. However, Participants \#7 and \#19 admitted a lesser degree of concern due to having older children (\#7) and or not being home much (\#19). Nevertheless, regardless of the reasoning for the participants' concerns or even a lack of strong concern, the general consensus seemed to be the valuing of knowledge gained from the notification process.

First of all, it should be noted that the law enforcement agency that oversaw the notification process for this rural community did so on a regular basis using a personal touch of going door-to-door with flyers concerning any RSO activity in terms of residency. Secondly, while nothing was specifically asked about the notification process, several of the participants expressed opinions. The comments ranged from "I am very happy that our sheriff handles the situation the way he does and informs everybody in the neighborhood of this man living here" (\#2) and "I am glad that the sheriff's office sends out notices. I didn't realize that they would keep doing this every year, and I am glad because what if I had just moved in the house" (\#5), to admitting having not given it "much thought until I got the notification" (\#4). Participant \#4 also stated appreciation for knowing what the offender had done as it made "a difference" and further explained,

Because if it's like this guy, it is violent. He intended on and forcibly raped a girl...statutory rape. The odds are that I am not really going to have to worry about that type of person because of the fact that it is not the same. So you know, it helps to know, you know do I have to worry about this person or can I just put it like in the back of my mind. I was more worried in Florida because they didn't tell you the reason why. So, that it was like it made me wonder. I was worried, but I wasn't sure what I should be worried about. At least this way I understand what he did. Because you know given the facts.

Just one participant (\#1) expressed being upset by the notification process, but not for reasons of fear, but because of feeling it was not "right or fair" due to fact that the offender was now elderly. The comment made was as follows: "His crime was over 20 years ago. He is an older man now and is just trying to live his life, but he can't do that." Participant \#20 also commented about the same sex offender in terms of not necessarily being concerned, but seemed to appreciate being aware. The sentiment expressed was "[He is] not obviously an active offender. I mean, he is physically incapable of offending; he's in a wheelchair.” In a somewhat similar vein, Participant \#8 commented,

I think the ones that have been convicted and labeled - it (notification process) serves a great purpose. They are not going to get away. They have rules they have to follow and comply with. They know they are being watched, it is all well and good, but after that leave them alone.

However, others held stronger views and concern, particularly due to having personal knowledge of the offender and the 
offence, which alludes to the issue of notifications not necessarily providing this information. Participant \#3 had personal knowledge regarding two RSOs and shared having misgivings regarding both of them due to having casual interactions with both offenders. The one is a level 2 offender who Participant \#3 frequently passes on the street and stated the young man always says hello. However, \#3 admitted, "I talked to him once and asked if he could read...he said no, but yet his crime was interacting [inappropriately] with a young girl online." Participant \#3 is also convinced that the older RSO is "manipulative" and ergo not to be trusted. Nevertheless, Participant \#12 tended to have an open attitude regarding the RSO nearby because a friend "likes him [the offender] and goes to church with him."

The participants who had knowledge of the offense all expressed negative reactions and attitudes toward the RSO. Participant \#14 plainly stated, "After reading what he [RSO] did, it just makes me sick." In like manner, Participant \#16 remarked, "I have no to desire to get to know him [RSO]." Furthermore, several noted that knowledge of the level of the crime made a difference in terms of their feelings and responses as stated by Participant \#10 -

I think it goes down to the point that it depends on, to me, what level he is. This gentleman was a level 4 violent sex offender. I found out that while I knew him he had been arrested on other charges before that I didn't know had taken place. Similarly, Participant \#8 related.

Personally, I draw a distinction between the levels 1-4. I know this guy's family history; I know that it was computer sex. I am satisfied that he is not a risk to little girls, women, or little boys, or anyone. He's not a risk. If I thought he was a risk, I wouldn't rent to him. I don't believe he's going to, excuse the euphemism, "poop in his nest." I think that they have enough sense that if they are going to misbehave, it isn't going to be at home. I would be perfectly comfortable living beside a sex offender unless, of course, his offense was beating up and raping old ladies in a nursing home. Then, I am going to be like the drunk, I'm going to want to beat him up. So I am kind of mixed.

Participant \#13 also shared the opinion that the level or type of offense made a difference as he viewed statutory rape as being "different" whereas if the action was "for a young kid, a young child, ...that one made me real uncomfortable." Similarly, Participant \#15 shared that prior to the arrest of the RSO, they were friends, but now, "we don't have any contact with him anymore. We just don't at all." However, conversely, Participant \#6 had known the offender for an extended period of time and shared that knowledge of the offense had "no effect" on his life.

In summation of the data, several participants indicated in their responses that the nature of the crime and perceived threat to themselves or others, based on the timeframe since the crime as well as the severity of the crime, were the overwhelming causes for perceived fear. Additionally, some reported that despite how nice the offender was, they could not get past the nature and extent of the crime.

\section{Discussion}

The issue of knowledge appears to be a factor in either alleviating or increasing fear, which has been noted regarding media reports of offenders (Durling, 2006; Fortney et al., 2007; Proctor, Badzinski, \& Johnson, 2002; Witt \& Barone, 2004) as well as by the responses of the participants in this study. As expressed earlier, the focus of notification processes and laws is to provide the general citizenry with a sense of protection (Lave, 2011), which 70\% of the participants in the described study felt did make a difference, albeit, not necessarily in making them feel protected, but allowed them to make informed decisions regarding the sexual offender. Additionally, two of the participants who had previously lived in other states shared how much they appreciated the detailed information they received in this locale, particularly the type of crime and the type of victim. This alone highlights the need to review and possibly revise the notification procedures and content, thus creating a more standardized process so that the public can make informed decisions with respect to placing caution and fear into a proper context.

\section{References}

Ackerman, A. R., Harris, A. J., Levenson, J. S., \& Zgoba, K. (2011). Who are the people in your neighborhood? A descriptive analysis of individuals on public sex offender registries. International Journal of Law and Psychiatry, 34(3), 149-159. https://doi.org/10.1016/j.ijlp.2011.04.001

Anderson, A. L., Sample, L. L., \& Cain, C. M. (2015). Residency restrictions for sex offenders: Public opinion on appropriate distances. Criminal Justice Policy Review, 26(3), 262-277. https://doi.org/10.1177/ 0887403413513897

Bonnar-Kidd, K., (2010). Sexual offender laws and prevention of sexual violence recidivism. American Journal of Public Health, 100(3), 412-419. https://doi.org/10.2105/AJPH.2008.153254

Brannon, Y. N., Le venson, J. S., Fortney, T., \& Baker, N. (2007). Attitudes about community notification: Acomparison of sexual offenders and the non-offending public. Sex Abuse, 19(4), 369-379. https://doi.org/10.1177/107906320701900403

Cauffman, E., Piquero, A. R., Kimonis, E., Steinberg, L., Chassin, L., \& Fagan, J. (2007). Legal, individual, and 
environmental predictors of court disposition in a sample of serious adolescent offenders. Law \& Human Behavior, 31(6), 519-535. https://doi.org/10.1007/s10979-006-9076-2

Chajewski, M., \& Mercado, C. C. (2009). An evaluation of sex offender residency restriction functioning in town, county, and city-wide jurisdictions. Criminal Justice Policy Review, $20(1)$, 44-61. https://doi.org/10.1177/0887403408320845

Chwalisz, K., Shah, S. R., \& Hand, K. M. (2008). Facilitating rigorous qualitative research in rehabilitation psychology. Rehabilitation Psychology, 53(3), 387-399. https://doi.org/10.1037/a0012998

DeMichele, M., \& Payne, B. (2009). Offender supervision with electronic technology: Community Corrections Resource (2nd ed.). Washington, D.C.: Bureau of Justice Assistance: U.S. Department of Justice.

Durling, C. (2006). Never going home: Does it make us safer? Does it make sense? Sex offenders, residency restrictions and reforming risk management law. The Journal of Criminal Law and Criminology, 97(1), 317-363. http://scholarlycommons.law.northwestern.edu/cgi/viewcontent.cgi ?article $=7257 \&$ context=jclc

Duwe, G., \& Donnay, W. (2010). The effects of failure to register on sex offender recidivism. Criminal Justice and Behavior, 37(5), 520-536. https://doi.org/10.1177/0093854810364106

Ferrandino, J. (2012). Beyond the perception and the obvious: What sex offender registries really tell us and why. Social Work in Public Health, 27(4), 392-407. https://doi.org/10.1080/19371910903126663

Finkelhorn, D. (2009). The prevention of childhood sexual abuse. The Future of Children, 19(2), 169-194. https://doi.org/10.1353/foc.0.0035

Fortney, T., Levenson, J., Brannon, Y., \& Baker, K. J. (2007). Myths and facts about sexual offenders: Implic ations for treatment and public policy. The Journal of Sexual Offender, 2(1). Retrieved from http://www.sexual-offender-treatment.org/55.html

Freeman-Longo, R. E. (2001). Revisiting Megan's Law and sex offender registration: Prevention or problem. Retrieved from http://www.appa-net.org/eweb/docs/appa/pubs/ RML.pdf

Galeste, M. A., Fradella, H. F., \& Vogel, B. (2012). Sex offender myths in print media: Separating fact from fiction in U.S. newspapers. Western Criminology Review, 13(2), 4-24. Retrieved from http://www.westerncriminology.org/documents/WCR/v13n2/Galeste.pdf

Glaser, B. G., \& Strauss, A. L. (2009). The discovery of grounded theory: Strategies for qualitative research. Retrieved from http://www.transactionpub.com/

Groenewald, T. (2004). A phenomenological research design illustrated. International Journal of Qualitative Methods, 3(1), Article 4. Retrieved from https://sites.ualberta.ca/ iiqm/backissues/3_1/pdf/groenewald.pdf

Grubesic, T. H., Mack, E., \& Murray, A. T. (2007). Geographic exclusion: Spatial analysis for evaluating the implications of Megan's Law. Social Science Computer Review, 25(2), 143-162. https://doi.org/10.1177/0894439307298930

Jacob Wetterling Crimes against Children and Sexually Violent Offender Registration Act. Pub. L. 103-322, title XVII, subtitle A (Sec. 170101 et seq.), Sept. 13, 1994, 108 Stat. 2038 (42 U.S.C. 14071 et seq.)

Jacob Wetterling Resource Center. (2010). How we began and the need for transition. Retrieved from http://www.jwrc.org/WhoWeAre/History/tabid/128/Default.aspx

Lave, T. R. (2011). Throwing away the key: Has the Adam Walsh Act lowered the threshold for sexually violent predator commitments too far? Journal of Constitutional Law, 14, 391. Retrieved from https://www.law.upenn.edu/journals/conlaw/articles/volume14/issue2/Rice-Lave14U.Pa.J.Const.L.391(2011).pdf

Levenson, J. S., \& D’Amora, D.A. (2007). Social policies to prevent sexual violence: The emperor's new clothes? Criminal Justice Policy Review, 18,168-199. https://doi.org/10.1177/ 0887403406295309

Miller, J. A. (2010). Sex offender civil commitment: The treatment paradox. California Law Review, 98(6), $2093-2128$. http://scholarship.law.berkeley.edu/cgi/viewcontent.cgi?article=1064\&context=californialawreview

Moustakas, C. (1994). Phenomenological research methods. Thousand Oaks, CA: Sage. https://doi.org/10.4135/9781412995658

Newburn, K. (2010). The prospect of international sex offender registry: Why an international system modeled after United States sex offender laws is not an effective solution to stop child sexual abuse. Wisconsin International Law Journal, 28(3), 547-583. Retrieved from https://hosted.law.wisc.edu/wordpress/wilj/2011/10/29/the-prospect-of-an-international-sex-offender-registrywhy-a 
n-international-system-modeled-after-united-states-sex-offender-laws-is-not-an-effective-solution-to-stop-child-sex ual-abuse-by-karne-newbur/

Office of Justice Programs: Office of Sex Offender Sentencing, Monitoring, Apprehending, Registering, and Tracking [SMART]. (n.d.). Legislative history. Retrieved from United States Department of Justice website: http://www.ojp.usdoj.gov/smart/legislation.htm

Payne, B. K., Tewksbury, R., \& Mustaine, E. E. (2010). Attitudes about rehabilitating sex offenders: Demographic, victimization, and community-level influences. Journal of Criminal Justice, 38(4), 580-588. https://doi.org/10.1016/j.jcrimjus.2010.04.029

Proctor, J., Badzinski, D., \& Johnson, M., (2002). The impact of media knowledge and perceptions of Megan's Law. Criminal Justice Policy Review, 13(4), 356-384. https://doi.org/10.1177/088740302237804

Registered Sex Offender and Victim Advocates. (2013). Public perceptions about sex offenders and community protection policies. Retrieved from http://www.rsova.info

Saxer, S. R. (2009). Banishment of sex offenders: Liberty, protectionism, justice, and alternatives. Washington University Law Review, 86(6), 1397-1453. http://openscholarship.wustl.edu/cgi/viewcontent.cgi?article=1139\&context=law_lawreview

Skelley, B. (2011). Sex offender assessment panels: A failed attempt to protect the public from Louisiana's most violent predators. Louisiana Law Review, 72(1), 287-324. Retrieved from http://digitalcommons.law.lsu.edu/cgi/viewcontent.cgi?article=3056\&context=lalrev

Stevens, P. S. (2012). History of the sex offender registry. Retrieved from http://sex-offender-registry-review.toptenreviews.com/history-of-the-sex-offender-registry.html

Tewksbury, R. (2005). Collateral consequences of sex offender registration. Journal of Contemporary Criminal Justice, 21(1), 67-81. https://doi.org/10.1177/ 1043986204271704

Tewksbury, R., \& Lees, M. (2006). Perceptions of sex offender registration: Collateral consequences and community experiences. Sociological Spectrum, 26(3), 309-334. https://doi.org/10.1080/02732170500524246

U.S. Department of Justice: Office of the Attorney General. (2008). The national guidelines for sex offender registration and notification. http://www.goccp.maryland.gov/msac/documents/final_sornaguidelines.pdf

Wagner, C. (2011). The good left undone: How to stop sex offender laws from causing unnecessary harm at the expense of effectiveness. American Journal of Criminal Law, 38(2), 263-288. https://www.tib.eu/en/search/id/BLSE\%3ARN292978570/The-Good-Left-Undone-How-to-Stop-Sex-Offender-La ws/

White, K. (2008). Where will they go? Sex offender residency restrictions as modern-day banishment. Case Western Reserve Law Review, 59(1), 161-189.

http://scholarlycommons.law.case.edu/cgi/viewcontent.cgi?article=1802\&context=caselrev

Witt, P., \& Barone, N. (2004). Assessing sex offender risk: New Jersey methods. Federal Sentencing Reporter, 16(3), 170-175. https://doi.org/10.1525/fsr.2004.16.3.170

Zandbergen, P. A., \& Hart, T. C. (2006). Reducing housing options for convicted sex offenders: Investigating the impact of residency restriction laws using GIS. Justice Research and Policy, 8(2), 1-24. https://doi.org/10.3818/JRP.8.2.2006.1

\section{Copyrights}

Copyright for this article is retained by the author(s), with first publication rights granted to the journal.

This is an open-access article distributed under the terms and conditions of the Creative Commons Attribution license which permits unrestricted use, distribution, and reproduction in any medium, provided the original work is properly cited. 